\title{
Are the view of Helicobacter pylori colonized in the oral cavity an illusion?
}

JKC Yee

Urea breath test (UBT), as a leading preferred non-invasive diagnostic technology, but may not be able to detect oral $H$. pylori. With negative results of UBT, the patient may have an oral infection. On the basis of the fact of success, eradication rate may increase by $21 \%$ in the $95 \% \mathrm{Cl}$ range after the elimination of oral $\boldsymbol{H}$. pylori, the author believes oral $\boldsymbol{H}$. pylori does exist and the oral cavity is the second colonized site aside its primary site of the stomach. $\boldsymbol{H}$. pylori migrated out of Africa along with its human host circa 60000 years ago; they are not lives in stomach only. In this review article, evidence established in recent years studies with use more appropriate technology had been listed and discussed. The author considers the oral cavity is a black hole for $\boldsymbol{H}$. pylori infection that significant effective on gastroenterology and another medical field. The role of the oral cavity as the source of $\boldsymbol{H}$. pylori infection is so controvert in past years. It seems like a human being having a second-time face to discover $H$. pylori in the history.

Experimental \& Molecular Medicine (2017) 49, e397; doi:10.1038/emm.2017.225; published online 24 November 2017

\section{INTRODUCTION}

Most scientists in this field proposed there are no living $H$. pylori lives in the mouth and positive response of the oral cavity by PCR due to reflux from the stomach. The survive of H. pylori in the oral cavity lives for only a few hours. If this proposal is right, then the dead bacteria should not have any negative effective on eradication of stomach $H$. pylori infections. However, there are a number of reports that indicated eliminated oral $H$. pylori may help more patients recover from stomach infection. ${ }^{1,2}$ These reports concluded that there is a significant relationship between stomach and oral $H$. pylori infection. This finding greatly explains why the annual $H$. pylori recurrence rates were so high with the first year being $13.2 \%$ followed by the second-year and the third-year both being $18.4 \%$, due to oral cavity infection. ${ }^{3}$ In developed countries, the $H$. pylori recurrence rates after successful eradication were very low-which means that discrepancy exists and is likely determined by economic status. However, it still continues to be a considerable controversy on the fundamental issue of oral H. pylori. For example, how the stomach infection occurs? H. pylori stay in the mouth, then via the oral cavity come down to stomach? What is the premium function of the oral cavity in this process? Or the mouth is a second colonization site of $H$. pylori? Hence, if the mode of $H$. pylori transmission remains unknown, we are unable to interrupt the spread of infection. The resolution on these disputable issues is so important because the majority of physicians and scientists in this field do not consider oral $H$. pylori are living bacteria. I estimate $\sim 20 \%$ of the population of Asia having $H$. pylori of oral cavity. ${ }^{4}$ There are $\sim 280$ million people of China having oral $H$. pylori infection. There are 280 million people have the problem of recurrences of stomach $H$. pylori infection. The abuse and overuse of antibiotics occur everywhere. ${ }^{1,3,4}$ As today, antibiotic pollution that appears in food, water, even in children's urine that become a serious concern. ${ }^{5}$ If we do not stop this abuse, antibiotic may kill 80000 per year and cost 11.7 billion dollars as medical expenses in China. This review will provide facts that indicating oral $H$. pylori infection exist and discuss how to eliminating them without antibiotic.

\section{THE CLOSE RELATIONSHIP BETWEEN PERIODONTAL HEALTH AND $H$. PYLORI INFECTION}

Dye BA et al. ${ }^{6}$ report that a clinical periodontal study on 4504 participants during 10 years period that show the close relation between the depths of advanced pockets and a positive blood test for $H$. pylori antibodies. They concluded that poor periodontal health having periodontal pockets $>5 \mathrm{~mm}$ always associated with $H$. pylori infection of adults in US population. ${ }^{6}$ Fernández-Tilapa $\mathrm{G}$ et al. ${ }^{7}$ use blood $H$. pylori antibody tests found that the prevalence of $H$. pylori in oral cavity was higher (18.5\%) among seropositive subjects compared with seronegative persons in México. However, they concluded there were no 
association between the presence of $H$. pylori and oral hygiene habits. Furthermore, Nisha KJ et al. ${ }^{8}$ reported that $H$. pylori may colonize in dental plaque that shows a strong relation with periodontal diseases. Tsami A et al. ${ }^{9}$ also detected $H$. pylori presenting in the subgingival dental plaque of children as well as their family.

Several reports have indicated that $H$. pylori colonies could be grown only from root canals but not from plaque. The root canals of endodontic-infected teeth could be a reservoir for living $H$. pylori that could serve as a potential source of transmission. ${ }^{10,11}$

Recent studies have shown that they consistently found $H$. pylori live in the oral cavity that strong like with recurrence of stomach $H$. pylori infection. Furthermore, in a review article, they indicted the treatment of periodontal disease may help the improvement of the symptoms of $H$. pylori-positive dyspeptic patients. ${ }^{2}$ A large size of a clinical study of China shown a high percentage of adults suffers from oral $H$. pylori infection, which also strong like with oral diseases; such as periodontal diseases and caries. ${ }^{12}$

A review and Meta-analysis included 48 articles and 12 clinical trials, as well as a meta-analysis designed in 2011 that indicated a strong association between $H$. pylori infection of mouth and $H$. pylori stomach infection. They found $H$. pylori are the etiologic agent of periodontal disease. They concluded that there is a strong relation between mouth and stomach $H$. pylori infection. ${ }^{13}$ Recent several meta-analyses report a similar conclusion regarding oral cavity and stomach. ${ }^{14-17}$ The total participants involved in the above meta-analyses are more than 20000 individuals (Table 1).

Furthermore, combining full-mouth disinfection plus triple therapy on periodontitis patients for oral $H$. Pylori infection increasing eradication success rate of stomach $H$. pylori infection. ${ }^{18}$

Although meta-analysis provided a right direction of periodontal diseases and $H$. pylori infection, however we should also discussion each individual study further since they reported a correlation in result but with negative conclusion, For example, A clinical study shows $H$ pylori was detected in specimens of 34 patients (54\%). Because all of the cultures of dental plaque were negative. They concluded that dental plaque or dentures are not an important reservoir for $H$ pylori and are probably not a significant factor in transmission of the organism. ${ }^{19}$ Author did not agree with their conclusion because the method of cell cultures used for high concentration of $H$. pylori in stomach not for oral cavity where the concentration of $H$. pylori at very low level. Author will discussion why failure of cell cultures occur in later section.

However, there are a number of published articles that indicate there were no correlations between $\mathrm{H}$. pylori gastritis and dental hygiene or periodontal disease. They concluded that either dental plaque or dentures have nothing to do with stomach $H$. pylori infection. At least, they consider oral H. pylori is not a significant factor cost stomach infection and they areorganisms in transmission in the mouth. However, the key fact is that they did indeed detect $H$. pylori in the oral cavity, but with a different view of conclusion. ${ }^{20,21}$ They think the results of such studies should be considered prudently because the oral cavity is the residence of several ureaseproducing species, including Streptococcus spp., Haemophilus spp. and Actinomyces spp. Those organisms also have high urease activity in dental plaque which is nothing to do with oral H. pylori. While the diagnosis of $H$. pylori in gastric samples you may see the microscopic appearance such as Gram-negative, curved or spiral-shaped rods which may not as $H$. pylori. If you use microscopic appearance as a standard to check oral samples you can found many species have spirochetes appearance, including Treponema spp. so this standard has low specificity. We should be prudent to make any conclusion. ${ }^{22}$

Namiot et al..$^{23}$ conducted a clinical study. They reported in $65.6 \%$ of an adult having $H$. pylori antigens exist in dental plaque. They concluded the occurrence of $H$. pylori antigens of dental plaque of natural teeth is not link with oral health status. After remove dental plaque of natural teeth and removable dentures, the H. pylori still stay in mouth. However, Silva et $a .^{24}$ reported $H$. pylori was existing in the supragingival plaque, but not in the subgingival plaque in the case if the patient has periodontal disease and upper gastric diseases. They concluded $H$. pylori may colonize in the supragingival site and it is strong like with oral hygiene. Chaudhry et al. ${ }^{25}$ suggested use two genes of the bacterium simultaneously amplified as compared to one gene amplification only then we have better

Table 1 Meta-analysis of periodontal disease and oral $\boldsymbol{H}$. pylori associated with stomach $\boldsymbol{H}$. pylori infection published during 2011-2016

\begin{tabular}{|c|c|c|c|}
\hline Author & Year & Number & Conclusion \\
\hline Ren et al. ${ }^{15}$ & 2016 & 691 participants & Periodontal therapy increased eradication rate of stomach infection \\
\hline Sayed et al. ${ }^{16}$ & 2014 & 4959 participants. Articles published during 1990-2012 & Oral H. pylori increased stomach re-infection \\
\hline Adler et al. ${ }^{13}$ & 2014 & $\begin{array}{l}>5000 \text { participants } \\
48 \text { articles and } 12 \text { clinical trials }\end{array}$ & Close relation oral $H$. pylori and stomach $H$. pylori infection \\
\hline Marbaix et al. ${ }^{14}$ & 2013 & $\begin{array}{l}>5000 \text { participants } \\
\text { Included } 48 \text { articles }\end{array}$ & Close relation oral $H$. pylori and stomach $H$. pylori infection \\
\hline Navabi et al. ${ }^{17}$ & 2011 & 1861 participants & Close relation oral $H$. pylori and stomach $H$. pylori infection \\
\hline Zou and $\mathrm{Li}^{71}$ & 2011 & $\begin{array}{l}\text { >6000 participants } \\
\text { Articles published during 2010-2011 }\end{array}$ & Close relation oral $H$. pylori and stomach $H$. pylori infection \\
\hline
\end{tabular}


chance to found $H$. pylori in dental plaque which may be a reason why some report found no $H$. pylori in dental plaque.

Yang J et al. ${ }^{26}$ reported a clinical study including 212 Han Chinese non-smoking adults. The results indicated that $H$. pylori positive status significantly increased the risk of periodontal diseases. Following is a summary table that listed all articles published from 1995 to April 2016 that indicated a close association of oral $H$. pylori and periodontal diseases in various countries with a data of a total of 61299 individuals (Table 2).

In recurrent aphthous stomatitis, there was a strong relationship between oral $H$. pylori infection and stomach infection. Also, H. pylori may play an etiological role. ${ }^{27}$ An article indicated oral $H$. pylori may be associated with leukoplakia and lichen planus oral lesions. ${ }^{28}$

Since oral $H$. pylori infection has associated with stomach diseases, they reported periodontal treatment may have positive effective on systemic drug therapy that increasing eradication success rate on stomach treatment and reducing recurrence of stomach $H$. pylori infection..$^{29}$ They found the $H$. pylori-positive rate in the healthy periodontal group was $15.38 \%$, but it was $72.73 \%$ in periodontitis group was. They consider the dental plaque can be one of the main causes of recurrence infection of stomach $H$. pylori infection. The oral $H$. pylori can also be the source of oral-oral transmission..$^{30}$ Conclusively, a new strategy which concomitant eradication in oral and gastric infection can result in clearance of $H$. pylori infection. ${ }^{31,32}$ Further reports found same strain of $H$. pylori simultaneously exists in plaque and gastric mucosa. There was a positive correlation between the collected indices and quantity of $H$. pylori colonization. ${ }^{33}$ There might be a relation between oral of $H$. pylori and oral lesions. Therefore, they suggested that we should have an early detection and eradication of oral $H$. pylori, especially important in high-risk patients. ${ }^{34-37}$ Cellini et al. found $H$. pylori exist in

Table 2 All articles published from 1995 to 2016 regarding the discussion on periodontal disease associated with oral $H$. pylori

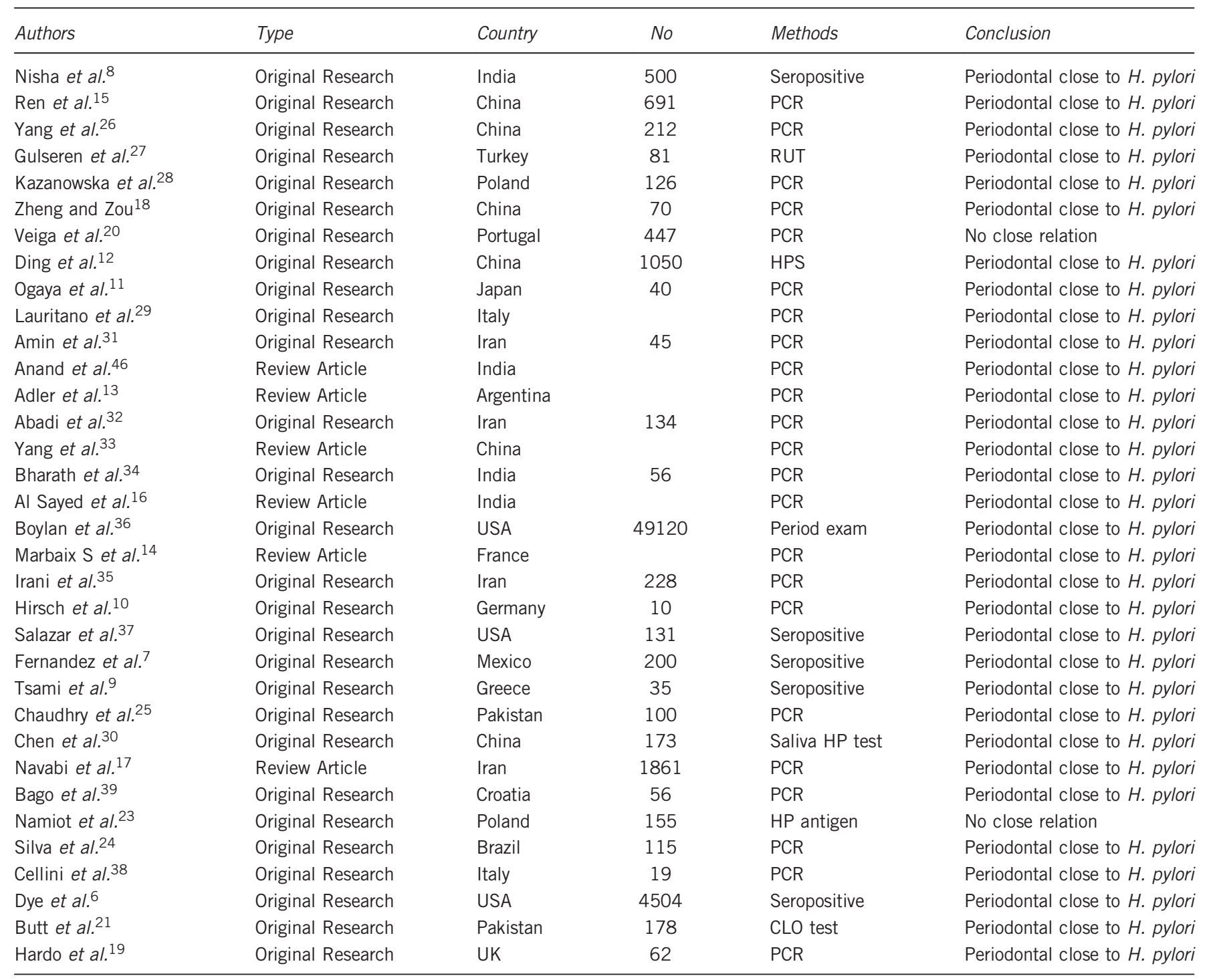


the esophagus and human saliva sample. They suggest that saliva and the esophagus may be a source of stomach $H$. pylori infection. ${ }^{38}$ Furthermore, Bago et al. ${ }^{39}$ reported that almost half of the patients suffer from gastric $H$. pylori harbored the same bacterium in the oral cavity. After the eradication therapy of stomach infection, $H$. pylori was not detected in the oral cavity, they proposed high effectiveness of the therapy protocol in the oral cavity may not help stomach recover. They consider oral $H$. pylori as a transient character. However, Bago et al..$^{39}$ is only one study that shows oral $H$. pylori was clean after eradication on the stomach, which did not agree with all remaining studies on this subject in past 20 years.

\section{THE ASSOCIATION BETWEEN STOMACH AND ORAL H. PYLORI INFECTION}

Whether the oral $H$. pylori are transient or permanent in the mouth, the fundamental question is, 'Can oral $H$. pylori be a reservoir for gastric $H$. pylori infection?' One might be first address whether there is an association between oral and gastric H. pylori carriage. Several studies have reported there is positive link oral with gastric $H$. pylori. ${ }^{40-42}$ Conversely, there was a study that indicated there were no such association. ${ }^{43}$ Song et al. ${ }^{44}$ reported that $H$. pylori exist in the oral cavity of $97 \%$ of patients that has characteristic distribution independent of the status of stomach infection. This is why they consider $H$. pylori may belong to the normal oral microflora, which is nothing link with stomach infection. However, recent studies show the bacterial involving oral cavity and stomach has an identical or closely species which related strains of $H$. pylori that provided a good evidence of the role of the oral cavity link with gastric infection.

One of the articles has a view against oral $H$. pylori link with stomach infection because they found oral and stomach $H$. pylori have different genotypes. This study shows that more than one $H$. pylori strain exists in the oropharynx and stomach at the same patient. They concluded that oropharyngeal infection is independent of the gastric infection. ${ }^{10}$ However, remarkable genotype diversity among stomach, saliva and stool that showed that more than one $H$. pylori genotype may exist in the same patient. ${ }^{45}$ However, there is an article reported the same strain of $H$. pylori simultaneously exists in plaque and gastric mucosa. ${ }^{34}$

There is increasing evidence recently regarding the role of the oral cavity in the transmission of $\mathrm{H}$. pylori to stomach use new methods to detecting $H$. pylori in the oral cavity. That evidence continually supporting the view of the association between oral and stomach $H$. pylori infection. But, Young et al. ${ }^{46}$ Consider this subject requires considerably more clinical studies before make a definite conclusion; especially we need a technology to confirmed oral $H$. pylori exists. As long as we can confirm oral cavity involving, then we can do preventive measures oral transmission. Rasmussen et al. ${ }^{47}$ report a strong link between oral $H$. pylori and gastric infection in Brazilian community. In their finding, the $H$. pylori exist in the oral cavity with different distribution between saliva and dental plaques that may suggest a potential link between oral infection and recurrence of stomach infection. Morales-Espinosa et al. ${ }^{48}$ report that in Mexico, many patients have $H$. pylori in the oral cavity suffer from gastric symptoms. Therefore, they suggest we should have the combination of treatments on both sites immediately.

There are several reports indicated eliminating dental plaque can significantly improving $H$. pylori of the gastric mucosa. ${ }^{41}$ Zaric S et al. ${ }^{49}$, report a combination periodontal treatment and drug systemic therapy can increasing the eradication success rate of stomach $H$. pylori infection and decreasing the risk of recurrence of stomach infection. Therefore they suggested that we should do professional plaque removal and oral hygiene procedures along with the antibiotic treatment of stomach H. pylori. infection. ${ }^{50,51}$ Since the cagA gene exists in both gastric biopsies and saliva, as well as dental plaque ${ }^{52}$ this evidence further supports the view of a close association relationship between oral and stomach $H$. pylori infection. Al Asqah et al..$^{33}$ conducted a clinical study that shows $65 \%$ of patients have dental plaque $H$. pylori. Among them, there were $>50 \%$ patients' harbored same bacteria in their stomach. In the same manner, the periodontitis patients had a significantly higher percentage of $H$. pylori in their dental plaque and the stomach that compared with patients without periodontitis. In addition, $78 \%$ of patients have $H$. pylori dental plaque in periodontitis group versus only $30 \%$ in non-periodontitis group. The coexistence of $\mathrm{H}$. pylori in both dental plaque and the stomach had been observed. ${ }^{53}$ Liu $\mathrm{Y}$ et al..$^{54}$ found dyspeptic patients with gastric infection are more likely to harbor $H$. pylori in their mouth that show a close association between $H$. pylori in the oral cavity and the stomach. Loster et $a .^{55}$ found an interesting relationship of the lengths of dentist occupations. The dentist may carry gingival sulcus infection with $H$. pylori after a long time working on a patient with oral $H$. pylori infection that indicating oral $H$. pylori can be contagious through dental instruments. Yee et al. ${ }^{56,57}$ had conducted several large clinical trials in China where there were $>10000$ individuals involved. More authors in addition to Yee et al. ${ }^{56,57}$ conducted similar clinical trial in various countries. All of them found a strong association of oral and stomach $H$. pylori infection Table 3.

However, Silva et al. ${ }^{58}$ had different viewpoints. Because they cannot found $H$. pylori in any oral samples who suffer from stomach $H$. pylori infection. Also, they found no genotype cagA in oral samples and cannot characterize vacA genotype in an oral sample of $>30$ patients.

\section{WHY THE TRADITIONAL DRUG ERADICATION OF GASTRIC $\boldsymbol{H}$. PYLORI INFECTION IS INEFFECTIVE AGAINST ORAL $\boldsymbol{H}$. PYLORI INFECTION?}

In 1999, Dore-Davin et al. ${ }^{59}$ first discovered after systematical eradication on stomach $H$. pylori infection that had no effect on oral $H$. pylori. Miyabayashi et al. ${ }^{60}$ further reported the eradication success rate of stomach $H$. pylori infection was significantly lower in the oral $\mathrm{H}$. pylori-positive cases compared with oral $H$. pylori-negative cases at 4 weeks after drug treatment. Two years later, they found $95.8 \%$ of patient had 
no stomach $H$. pylori infection with oral $H$. pylori-negative cases but they found only $69.5 \%$ of patient with no stomach $H$. pylori infection with oral $H$. pylori-positive. They concluded that oral $H$. pylori infection affected eradication successes rate and oral $H$. pylori infection has a strong link with a recurrence of gastric infection. ${ }^{60}$ Since 1999, there are numerous studies that show when patients received drug treatment on stomach H. pylori infection that cannot clean up oral $H$. pylor. ${ }^{1,32,39,61-64}$ All later reports support Dore-Davin's first discovery (Table 4).

In terms of how to treat an oral $H$. pylori infection, there are a number of studies showing that mouth rinse treatment alone or combined with periodontal therapy may eliminate oral H. pylori infection and increase the eradication success rate of stomach $H$. pylori infection. ${ }^{1,2,63}$ A clinical study showed that the symptoms of $H$. pylori-positive dyspeptic patients may improve by oral treatmet. ${ }^{2}$ There are three studies ${ }^{65-67}$ that evaluated the effectiveness of periodontal treatment on H. pylori of mouth. They reported that patient received periodontal treatment may decrease plaque H. pylori. After treatment, if those patients still suffer from plaque H. pylori then followed a combination of treatment with triple therapy. Jia et al. ${ }^{67}$ proposal a periodontal treatment before eradication on stomach $H$. pylori infection. They reported that the prior periodontal intervention significant increasing eradication of stomach $H$. pylori infection of dyspeptic patients. After half year, the stomach $H$. pylori infection of the group received periodontal treatment has much lower than the group received no periodontal treatment. However, our studies ${ }^{1}$ shown that patients who received teeth cleaning had no effectiveness on $H$. pylori infection of mouth by statistical analysis. The special mouth resin is best effective in eliminating oral $H$. pylori infection that I will discussion it at the end.

The reason why eradication on stomach $H$. pylori infection has no effective on $H$. pylori infection of the mouth, because $H$. pylori exist in between the teeth and gums called, an area referred to as the 'bio- film membrane' (Biofilm), also we called as plaque barrier. The drug cannot penetrate it when the patient received symmetrically eradication. This is why the conventional treatment on stomach $H$. pylori infection had no effect on oral $H$. pylori; especially it exists in dental plaque.

\section{THE ERADICATION OF STOMACH H. PYLORI INFECTION FACES MORE CHALLENGING THAN EVER DUE TO PROGRESSIVE LOSS EFFICACY OF TRADITIONAL THERAPY}

There were several proposals how to providing treatment after failure of second-line therapies. One of them is the endoscopicguided antibiotic susceptibility testing. However, according to

Table 3 Studies show the association of oral and stomach $H$. pylori infection

\begin{tabular}{|c|c|c|c|c|}
\hline Author & Country & No & Method & Conclusion \\
\hline Yee et al. 20 & China & $>10000$ & HPS & Association of Oral and stomach H. pylori \\
\hline Medina et al. ${ }^{51}$ & Argentina & 8 & PCR & Association of Oral and stomach H. pylori \\
\hline Eskandari et al. 50 & Iran & 67 & PCR & \\
\hline Rasmussen et al. ${ }^{47}$ & Brazil & 78 & PCR & Association of Oral and stomach H. pylori \\
\hline Loster et al. ${ }^{55}$ & Poland & 46 dentists & Serological test & Association of Oral and stomach H. pylori \\
\hline Liu et al. ${ }^{54}$ & China & 443 & PCR & Association of Oral and stomach H. pylori \\
\hline Al Asqah et al. ${ }^{53}$ & Saudi Arab & 101 & Urease test & Association of Oral and stomach H. pylori \\
\hline Silva et al. ${ }^{58}$ & Brazil & 62 & PCR & Association of Oral and stomach H. pylori \\
\hline Zaric et al. ${ }^{49}$ & Serbia & & PCR & Association of Oral and stomach H. pylori \\
\hline Jia et al. 67 & China & 56 & PCR & Association of Oral and stomach H. pylori \\
\hline Morales et al. ${ }^{48}$ & Mexico & 65 & PCR & Association of Oral and stomach H. pylori \\
\hline Oshowo et al. ${ }^{41}$ & UK & 208 & PCR & Association of Oral and stomach H. pylori \\
\hline Maplstone et al. ${ }^{40}$ & UK & 13 & Nested PCR & Association of Oral and stomach $H$. pylori \\
\hline
\end{tabular}

Table 4 Eradication on stomach $\boldsymbol{H}$. pylori infection had no effects on oral $\boldsymbol{H}$. pylori

\begin{tabular}{|c|c|c|c|c|c|}
\hline Author & Country & No & Time after eradication & Positive H. pylori in Oral & Positive H. pylori in Stomach \\
\hline Adadi et al. ${ }^{32}$ & Iran & 132 & After eradication & Patients carrying $H$. pylori & Patients carrying $H$. pylori \\
\hline Wang et al. ${ }^{1}$ & China & 159 & 4 weeks & $49.44 \%$ & $38.6 \%$ \\
\hline Song and $\mathrm{Li}^{63}$ & China & 391 & 4 weeks & $33.2 \%$ & $21.6 \%$ \\
\hline Bago et al. 39 & Croatia & 56 & 3 months & 0 & $21.7 \%$ \\
\hline Gao et al. 62 & China & 96 & 4 weeks & $62.8 \%$ & $32.4 \%$ \\
\hline Zaric et al. ${ }^{49}$ & Serbia & & & $52 \%$ & $23 \%$ \\
\hline Gebara et al. ${ }^{61}$ & Brazil & 30 & 3 months & $60 \%$ & $10 \%$ \\
\hline Miyabayashi et al. ${ }^{60}$ & Japan & 47 & 4 weeks and 2 years & $69.5 \%$ & $4.2 \%$ \\
\hline Dore-Davis et al. 59 & Swiss & 22 & 4 weeks & $57 \%$ & \\
\hline
\end{tabular}


the principal of Maastricht Guidelines, its role has expanded over, over again in past years. Several authors have reported the results of such proposal. The developed both efficacy clinical trials and cost-effectiveness trials against drug-resistant of treatment on stomach $H$. pylori infections. However, their results are not very successful, because antibiotic resistance is not the only main reason for the failure so far. The failure becomes a good attention in medical societies worldwide, special in Asia. ${ }^{68}$ It is time now we should establish a new view besides antibiotic resistance, which are the most important issues for the progressive loss of efficacy of eradication due to oral facts. Yee ${ }^{69}$ proposed the key conception that $H$. pylori have a second colonized site in an oral cavity in addition to the stomach. However, some authors said 'oral H. pylori cannot be cultured', ' $H$. pylori exists in the oral cavity are dead bacterial that has no effect on stomach treatment' and 'the oral cavity is not a colonized site,' which has become the main reasons to deny our version of oral $H$. pylori colonization. Because the majority of physicians working in gastroenterology field ignore the oral $\mathrm{H}$. pylori, 20\% of the population of Asia suffers from oral H. pylori infection ${ }^{1,3}$. Not only in Asia, Jonaitis et al. ${ }^{70}$ reported that after $H$. pylori eradication they frequency observe on $H$. pylori recurrence of peptic ulcer patients during 9 years in Lithuania The recurrence rate of $H$. pylori is high at $27.2 \%$. This number is very close that we found in Asia.

There is a motor circulatory system that I summarized that behind the negative impact of oral $H$. pylori on stomach treatment (Figure 1). This system contains two colonized sites of $H$. pylori in the upper digestive system. The primarily colonized site resides in the stomach and delivers $H$. pylori into the oral cavity by reflux as a conveyor. The oral cavity is a second colonized site for the culture of $H$. pylori; bacteria from this site drop into the stomach by the swallow reflex as a conveyor. Two colonized sites with two conveyors have been constructed to create a system that transports $H$. pylori along the upper digestive system. One of the colonized sites contains $H$. pylori, which results in a second colonized site being occupied by $H$. pylori. The recurrence of $H$. pylori infection occurs if one site had been treated by a drug and another site had not. The motor circulating system can transport $H$. pylori along the circle. A number of studies have shown that oral $H$. pylori were not eliminated in patients who received a drug treatment for stomach $H$. pylori. ${ }^{13,63,71}$ Traditional drug eradication and teeth cleaning had an effectiveness rate of less than $10 \%$. By statistical analysis, there was no effect all on oral

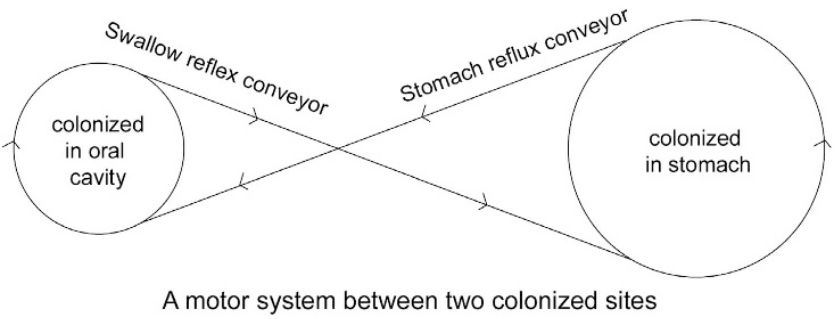

Figure 1 A motor system between two colonized sites. infection. A new strategy that concomitantly eradicates oral and gastric colonization would result in clearance of $H$. pylori infection and improve the eradication rate of gastric $H$. pylori. ${ }^{1}$

The discovery of oral $\mathrm{H}$. pylori is especially significant and meaningful because this motor system can explain why the recurrence of stomach $H$. pylori infection occurs.

\section{UREA BREATH TEST, A GOLD STANDARD DIAGNOSIS, USE ONLY FOR DIAGNOSIS OF STOMACH H. PYLORI INFECTION}

Urea breath test (UBT) $\mathrm{C}^{13}$ is a trusted diagnostic procedure used to identify stomach infections by $H$. pylori ${ }^{72}$ with the exception of a small number of false positives ${ }^{73}$ and they diagnosis for all $H$. pylori species not specific for CagA. ${ }^{74}$ The principle is based upon $H$. pylori to transform urea that released by $H$. pylori to carbon dioxide and ammonia. UBT is a popular method for diagnosis of $H$. pylori of the stomach. It holds efficacy at $96.7 \%$ sensitivity and $96.2 \%$ specificity. However, UBT is not used for diagnosis of oral $H$. pylori because $\mathrm{C}^{13}$ or $\mathrm{C}^{14}$ are not dissolved in the mouth during the testing. In medical practice, doctor considers you have no stomach $H$. pylori infection if you have negative results of UBT $\mathrm{C}^{13}$. In fact,doctor only pays attention to stomach infection. In their view, there is no $H$. pylori infection exist in anywhere besides stomach. This is traditional view on $H$. pylori infection for many years. However, the clinical study provides evidence that shown $H$. pylori oral infection are nonetheless present that also negatively effective on eradication on stomach $H$. pylori infection. In Asia, approximately $20-30 \%$ of the population having oral $H$. pylori infection but with negative UBT results. ${ }^{1}$ We developed a technology, H. pylori saliva test (HPS) that especially detecting oral $\mathrm{H}$. pylori ${ }^{4}$ and it is non-invasive, fast result and no equipment required during the testing.

It is controversial the fact of $H$. pylori exists in the oral cavity in past 20 years. It divided scientists into two groups. The majority scientism belongs to the first group that proposed that $H$. pylori stay in the oral cavity and that all positive results detected by PCR are fragments of dead bacteria that reflux from the stomach which could not be cultivated from PCRpositive samples. ${ }^{75}$ The proposal says the oral $H$. pylori come from stomach reflux was survive only a few hours in the mouth. Because oral cavity holds high oxygen concentration that kills all $H$. pylori. If the proposed view is correct, then the fragmented of bacteria have no negative effect on eradication of stomach $H$. pylori infections. ${ }^{75,76}$ However, their view contradicts with the studies of PCR recently published, ${ }^{77,78}$ the fact of the oral cavity may have hypoxia environment, ${ }^{35,79}$ the fact of oral $H$. pylori infection cannot clean up by traditional therapy. ${ }^{32,46}$ The fact that indicated $H$. pylori can be cultured from saliva sample if we use a new method of culture. ${ }^{1}$ The fact of oral and stomach has the same gene of $H$. pylori. ${ }^{7,55}$ It also contradicts with the evidence of the lower rate of eradication of stomach $H$. pylori when a person suffers from oral $H$. pylori infection $^{41}$ and the fact of results of all meta-analysis published in the past. ${ }^{13,71}$ Therefore, we proposed a new view that 
indicated $H$. pylori colonization of the oral cavity which may resolve all previous issues in past.

\section{WHAT IS THE BEST TEST FOR DETECTING $\boldsymbol{H}$. PYLORI OF THE ORAL CAVITY IN CLINICAL SETTINGS?}

PCR is a method often used for detecting oral $\mathrm{H}$. pylori, but its results have high variation. Some articles report the detecting rate were zero, but some articles report with $90 \%$ of positive response on the oral sample. Naturally, the scientific community very confused on the large variation of PCR testing results. We should find out why such discrepancies exist. ${ }^{22}$ In term of the requirement of the sample, expensive equipment required and technician for operating PCR testing. So PCR method is not a good and convenient way to detecting oral $H$. pylori for clinical settings. Therefore, a diagnostic method has a high sensitivity and specificity for oral sample should be established. We believe that HPS is a good and convenient test for diagnosis of $H$. pylori in the oral cavity. As long as we have an easy, accrue test, then the clinical trial can be carried out on a large number of patients to obtain a good size of clinical data, which will help to understand the strong links between oral and stomach $H$. pylori infection. We are able to establish the principles of evidence regarding oral $H$. pylori infection.

HPS is a lateral flow immunochromatographic test device that uses saliva as testing sample detecting oral $H$. pylori within few minutes. The principle of HPS is based on monoclonal antibody react with oral urease produced by $H$. pylori.

A laboratory study was conducted to determine its specificity. The following common bacteria of oral cavity were applied: Streptococcus gordonii, S. mutans (major pathogen of dental caries), S. salivarius, S. sanguinis and Veillonella parvula, Porphyromonas gingivalis (major pathogen of periodontitis), Gemella haemolysans, Granulicatella adiacens, Campylobacter rectus (major pathogen of periodontitis, species related to Helicobacter), Corynebacterium matruchotii, Bifidobacterium dentium, Actinomyces naeslundii, A. odontolyticus. All the above bacteria did not show interference or cross-reactivity with HPS test.

The sensitivity of the tests was $10 \mathrm{ng} \mathrm{ml}^{-1} \mathrm{H}$. pylori antigen. ${ }^{4}$

\section{DO ORAL H. PYLORI COME FROM STOMACH REFLUX?}

Do $H$. pylori in oral cavity come from stomach? That is one of the key issues that had been disputed in past. The author had a discussion on this question with the Nobel Laureate, Dr. Robin Warren. He indicated that oral $H$. pylori have to have come from the stomach through the reflux motion. In the case, if the patient had no $H$. pylori of the stomach, then why oral $H$. pylori exist? He believes very low numbers of bacteria lives in the stomach, but show false-negative UBT tests. They can through reflux the bacteria back to the oral cavity. Since scientist cannot culture on a positive sample by PCR that leading him to be trusted there are no living $H$. pylori in the oral cavity. His past lab experience also shows that he never managed to culture $H$. pylori from food, water or the mouth. He also advice when we say antigens of saliva or plaque, we should very carefully tell what methodology that to demonstrate those antigens. Another word he did not trust our new technology, HPS can detect oral H. pylori.

If a patient with $\mathrm{H}$. pylori infection of the stomach, then it is a good reason to believe the oral bacterial come from stomach reflux. But, with a UBT-negative patient and negative culture of stomach sample, we still detected H. pylori in the mouth. Also, we observe a large number of the patient which near 10000 patients with negative UBT test in several clinical studies but see oral $H$. pylori. This is why we confidence our data are reliable.

If we confirmed $H$. pylori-colonized in the oral cavity by culture saliva sample? What will be our next step? To follow up, we have conducted several studies in several subjects (1) What is the recurrence rate of stomach $H$. pylori infection each year to oral H. pylori? (2) Is it true that systematically drug treatments are not effective on oral $H$. pylori due to the construction of dental plaque structure? And (3) is the eradication rate of stomach $H$. pylori infection getting lower each treatment?

\section{CULTURE OF ORAL $\boldsymbol{H}$. PYLORI}

Krajden et al. ${ }^{80}$ in 1989 first reported the result of the culture of $H$. pylori gastritis. There was only one plaque had a positive result among seventy-one patients. All seventy-one saliva cultures show negative result. Since then, many attempted to cultivate oral $H$. pylori had been rarely successful worldwide (Table 5). 19,30,53,81-107 Indeed, published articles reported culture-positive rates are very low from various oral sample included saliva, dental plaque, and teeth. Majmudar et al., ${ }^{97}$ D'Alessandro and Seri, ${ }^{102}$ reported that they had been successfully cultured on saliva; however, Namavar et al. ${ }^{101}$ consider their results were false positives. The main difficulties of bacteria culture of the oral sample; are how to collect oral specimen; how to preserve it; there was a small number of colonies of $H$. pylori for culture and competition with other oral bacteria. Because the concentration of $H$. pylori of the stomach is three magnitudes higher than that of the oral cavity $\left(10^{5} \mathrm{CFU}\right.$ per $\mathrm{ml}$ versus $10^{2}$ CFUper $\left.\mathrm{ml}^{108-110}\right)$, it would be insufficient to use conventional stomach culturing techniques for detecting oral $H$. pylori. The method must be adapted to obtain a high positive rate of oral $H$. pylori culture with very low concentration of the oral sample. However, Dowsett et al. ${ }^{111}$ dispute that If such low concentration of $H$. pylori in the oral then it will be an insufficient number of bacterial result infection in any where. If this is indeed the case, the subsequent ability of oral $\mathrm{H}$. pylori has negative on stomach infection that may be questionable.

Author's lab had been culture $H$. pylori on saliva successfully since 2012. H. Pylori were isolated from saliva by pretreatment with Urea-Hydrochloric acid. ${ }^{108}$ We performed all the following tests to confirm $H$. pylori colonization:(a) Oxidase test (b) Catalase test (c) H. pylori antigen and antibody test (d) Microscopy observations.

I then communicated with Dr. Floyd E. Dewhirst, a significant scientist related to this field ${ }^{112}$ regarding confirmation on the result of $H$. pylori culture. He indicated that this is 
Table 5 Articles published since 1989 regarding culture of H. pylori in oral cavity

\begin{tabular}{|c|c|c|c|c|c|}
\hline Author & Country & NO & $\begin{array}{l}\text { Dental } \\
\text { plaque }\end{array}$ & Saliva & Teeth \\
\hline Krajden et al. ${ }^{80}$ & Canada & 71 & 1 & 0 & \\
\hline Oshowo et al. ${ }^{51}$ & UK & 180 & 2 & 0 & \\
\hline Cheng et al..30 & UK & 122 & 0 & 0 & 1 \\
\hline Luman et al. ${ }^{82}$ & UK & 109 & 0 & 0 & 0 \\
\hline Allaker et al. ${ }^{83}$ & UK & 100 & 0 & 0 & 0 \\
\hline Bernander et al. ${ }^{84}$ & Sweden & 114 & 0 & 0 & 0 \\
\hline Pustorino et al. ${ }^{85}$ & Italy & 83 & 5 & 0 & 0 \\
\hline Khandaker et al. ${ }^{86}$ & UK & 81 & 12 & 0 & 0 \\
\hline Ishihara et al. ${ }^{87}$ & Japan & 82 & 0 & 0 & 0 \\
\hline Hardo et al. ${ }^{19}$ & UK & 62 & 0 & & 0 \\
\hline Majmudar et al. ${ }^{88}$ & India & 40 & 40 & & \\
\hline Cellini et al. 89 & Italy & 31 & 1 & & \\
\hline Wahlfors et al. ${ }^{90}$ & Finland & 29 & 0 & 0 & \\
\hline Paronnet et al. ${ }^{42}$ & USA & 26 & & 3 & \\
\hline Namavar et al. ${ }^{91}$ & Holland & 20 & 1 & & \\
\hline D'Alessandro and Seri ${ }^{92}$ & Italy & 20 & 16 & & \\
\hline Ferguson et al. ${ }^{93}$ & USA & 16 & & 1 & \\
\hline Bickley et al. ${ }^{94}$ & UK & 15 & & 0 & \\
\hline Zhent et al. ${ }^{30}$ & China & 72 & & 31 & \\
\hline Chen et al. ${ }^{30}$ & China & 173 & & 69 & \\
\hline Zheng et al. ${ }^{96}$ & China & 163 & & 42 & \\
\hline Jiang et al. ${ }^{97}$ & China & 50 & & 13 & \\
\hline $\mathrm{Xu}$ et al. ${ }^{98}$ & China & 98 & & 21 & \\
\hline Agarwal et al. ${ }^{99}$ & India & 30 & 9 & & \\
\hline Czesnikiewicz-Guzik et al. ${ }^{100}$ & Poland & 100 & 45 & 55 & \\
\hline Czesnikiewicz-Guzik et al. ${ }^{101}$ & Poland & 100 & 46 & 54 & \\
\hline Loster et al. ${ }^{102}$ & Poland & 46 & & 22 & 20 \\
\hline Sudhakar et al. ${ }^{103}$ & India & 50 & 10 & & \\
\hline Teoman al. ${ }^{104}$ & Turkey & 67 & 17 & & \\
\hline Umeda et al. ${ }^{105}$ & Japan & 57 & 18 & & \\
\hline Goosen et al. ${ }^{106}$ & South Africa & 58 & 2 & & \\
\hline Majmudar et al. ${ }^{88}$ & India & 40 & 40 & & \\
\hline D'Alessandro et al. ${ }^{92}$ & Dell' Aquila & 20 & 16 & & \\
\hline $\begin{array}{l}\text { Namavar et al. }{ }^{91} \\
\text { Me'graud et al. }{ }^{122}\end{array}$ & Netherlands & 20 & & 3 & \\
\hline Wang et al. ${ }^{1}$ & China & 159 & & 94 & \\
\hline
\end{tabular}

not sufficient; we should have a full 1500 base 16S rRNA sequence of the isolate(s), and deposit the organisms in a national culture collection. With sequences and strains, the work is much stronger. He suggested the existing published studies show $H$. pylori can be cultured ${ }^{19,30,53,81-107}$ were not accountable because of none of them involved work with a full 1500 base 163r RNA sequence. He further indicated that the confirmation of culture results do not address transient (from burp) versus colonization. The oral microbiome and the gut microbiome each have greater than 700 species. The number of species shared between these two different habitats is one organism (Dialister pneumosintes). Even though vast quantities of oral bacteria are swallowed every day, and none (except one) colonizes the GI tract. Organic bacteria are very specific in their niche selection. There are nine niches in the oral cavity-subgingival, supra-gingival, tongue, tonsils, throat, attached gingiva, cheek, palate and saliva - and each niche has a distinct microbial (some overlap). The oral cavity has no site with gastric mucus and a $\mathrm{pH}$ of close to 1 . Where do we think it colonizes? Dr Dewhirst examined 27 subjects at the nine oral niches and reviewed the site sample reads by illuminate $16 \mathrm{~S}$ rRNA of the V1-V3 region. The region had about 100000 reads per site, so 100 reads are $0.1 \%$ of the total, plus he never saw $H$. pylori in any subject, at any site. Maybe his subjects did not have $H$. pylori in their stomach-this was not the point of the study. However, if we believe it is part of the microbiome in the mouth, then we need to show where in the mouth and at what percent of the population. If we find it at a high concentration in some oral niche, then fine-we can say we see it in at least one person at that particular concentration in this site/niche. However, this still does not address the question of transient versus commensal (or indigenous microflora). However, the author considered the clinical trial of eliminating $H$. pylori of the oral cavity which increase the successful rate of eradication of stomach $H$. pylori infection, and the best evidence of $H$. pylori in the oral cavity is commensal microflora. ${ }^{113}$

\section{ARE $\boldsymbol{H}$. PYLORI, A SEXUALLY TRANSMITTED BACTERIUM?}

If the view and evidence of $H$. pylori-colonized in the oral cavity are correct, then oral $H$. pylori can be sexually transmitted bacteria. On the other hand, if no $H$. pylori sexually transmitted diseases through oral exist, how we can believe that $H$. pylori exist in the oral cavity? Let us check the reference here to see what they reveal it.

Use blood $H$. pylori test run a clinical study on sex partners with man and woman. The results show $H$ pylori, the noninfected individual had statistically significant different prevalence rates of sex diseases. There were $83.3 \%$ vs $28.5 \%$, respectively, ${ }_{113,114}$ which may indicate $H$ pylori may be a sex transmitted bacterium.

Several studies have shown there is a strong relationship between sexually transmitted disease and ethnicity minorities' groups. ${ }^{15,116}$ They report the high rates of sexually transmitted infection occur in ethnic minorities.

Schutze et al. ${ }^{114}$ reported the $H$. pylori infection are contingent and transmitted between spouses. They found a recurrence of $H$. pylori spouses contains same identified strain gene type from spouses which is a good evidence that indicated H. pylori transmitted among spouses. However, they also found multiple strains exist in the same individual.

There were very limited articles published regarding sexual transmission of $H$. pylori among female sex workers. Eslick $\mathrm{GD}^{117}$ reported that so far even there is no study conducted a prevalence of $H$ pylori infection among female sex workers.

By theoretical analysis, they proposal $H$. pylori may colonize in the vaginal associated with yeast which constructed as biofilm formation, based on $H$. pylori exists in the biofilms 
among many bacterial species. This is why treatment failure occurs on yeast infection of the vaginal site. Eslick further hypothesized that $H$. pylori may colonize in an acidic vaginal environment that making vaginal as a source for sexual transmission for many species of bacteria. ${ }^{118}$

It was interesting an early case report that said they found 'spiral bacteria' with same strains of $H$. pylori in a woman's vagina who suffers from vaginitis. They describe spiral bacteria have comma-shaped rods (1-4 $\mu \mathrm{m}$ in length) with a corkscrew motion and its head bear with four to eight flagellae. This finding was a year before original article of Warren and Marshall that discovered on stomach $H$. pylori infection. Besides their appearance was similar, they also found that some of those spirals bacteria can be cultured under microaerophilic condition after $72 \mathrm{~h}$ incubation at $37^{\circ} \mathrm{C}$. The biochemical profile was very similar between spiral bacterial and $H$. pylori, but they did not run a further test to confirmed both of them are same species. Several articles indicated vertical transmission of $H$. pylori exists in the vagina during the birth process. The prevalence of $H$. pylori in pregnant women is about $20 \% .^{119,120}$

Kast RE reports a case that oral directly contacts with the nipple that may result in the retrograde propulsion of $H$. pylori into breast ducts which may lead to fibrocystic breast changes. It is a heterogeneous group of benign. In this case report, the woman had an $H$. pylori serology diagnosis as negative. However, after antibiotic eradication, she had no more pain and tenderness in breast and her breasts normalized. ${ }^{121}$ This was the reason leading his hypnosis that this woman had $H$. pylori retrograde into breast duct results $H$. pylori local infection. An article reported that mothers had been diagnosis with $H$. pylori antigenuria, the fecal of their half of breastfed 3 days old neonates found $H$. pylori. ${ }^{122}$ Are $H$. pylori transmitted from mother to neonates? Or from vertical transmission through vaginal delivery? They also found H. pylori exist in 4 out of 66 milk samples of mother suffered from $H$. pylori infection. ${ }^{123}$

Since oral sex is a very popular worldwide toady, the action of fellatio from woman to man, the $H$. pylori can transmit into the urethra that resulting infection. The question is why a large

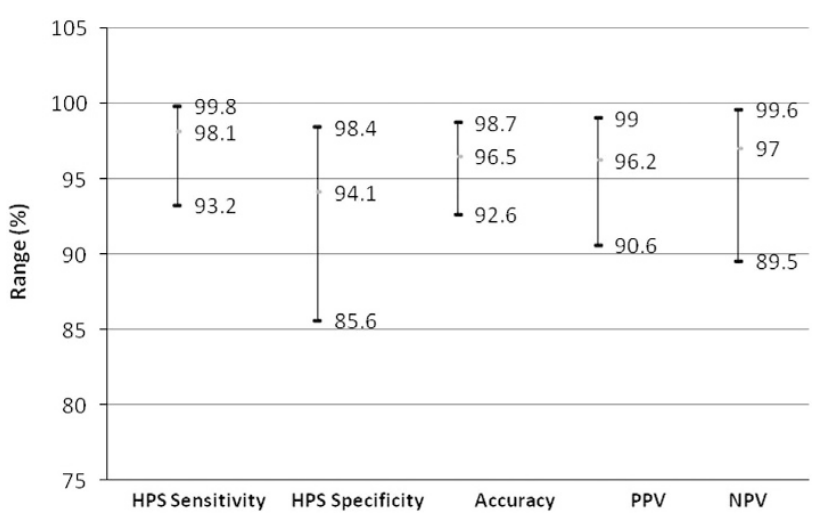

Figure 2 The accuracy of HPS confirmation by S-HP-C. proportion of males suffers with non-gonococcal urethritis, but no responsible bacteria found? This was an article suggested we should link urethritis with $H$. pylori infection and urethritis. ${ }^{124}$

When I have a personal conversation with Dr Kast RE who hypnosis on the link between prostate and $H$. pylori infection because fellatio was so popular.

An article reported vaginal yeasts as primary reservoir of $H$. pylori that may facilitate transmitted it to neonates. Mother with UBT positive may transmit $H$. pylori through vaginal delivery to neonates based on there are close associated oral yeasts of neonates and vaginal yeasts. ${ }^{125}$

Healthcare workers special baby delivery workers are more careful on $H$. pylori infection because it is contagious during vaginal delivery procedures.

An article indicated $H$. pylori may transmit through fellatio in the urethra. However, they proposal further research is required to defined the link between in $H$. pylori and urethritis. ${ }^{126}$

\section{PREVENTION ORAL-ORAL TRANSMISSION OF H. PYLORI}

Chow et al. ${ }^{127}$ found a strong association between prevalence of $H$. pylori infection and chopsticks user in Chinese society of Australia. They consider the saliva containers with $H$. pylori through chopsticks.

On the basis of the fact of oral to oral transmission, water carry and fecal to oral transmission, Dowsett et al. indicated H. pylori infection have been population dependent. ${ }^{128} \mathrm{~A}$ report from India that indicated there was a significant association between $H$. pylori infection and fingernail carriage based on $H$. pylori had been detected by PCR on beneath of fingernails. It is a customer of eating way in India. They use a finger to hold food. So washing hands before eating may be important for stop $H$. pylori's transmission.

By blood $H$. pylori antibody study, they found a strong link between $H$. pylori infection and crowded living condition. ${ }^{128}$ They further consider the socioeconomic status become an important issue that influences their finding. In developing countries, special in low socio-class children suffer from $H$. pylori infection become an important issue. There are no symptoms at all during a long period of latency until adult. Same way as stomach cancer resulted by stomach $H$. pylori infection usually does not show until older age. ${ }^{129}$ Regarding $H$. pylori transmission, mother as $H$. pylori carrier may be the main source for childhood $H$. pylori infection. ${ }^{30}$ A review article $^{131}$ reported the prevalence rates vary widely with different ethnic groups and geographical location. An oral-oral route of transmission had been mentioned with all studies that indicated a fact of $H$. pylori exists in the oral cavity.

Dowsett and Kowolik ${ }^{22}$ dispute that if the fact of $H$. pylori transmission through oral to stomach, then we naturally expect oral $H$. pylori infection should be more often than stomach H. pylori infection. Our studies have shown the discovery of oral $H$. pylori is especially significant and meaningful that may answer the question raised by Dowsett and Kowolik, because it 
is $\sim 20 \%$ of the population of Asia suffers from oral H. pylori infection.

\section{NON-ANTIBIOTIC TREATMENT FOR ELIMINATING ORAL H. PYLORI}

There is a non-antibiotic treatment for oral $H$. pylori infection available. ${ }^{1}$ Our studies indicated e-polylysine (L) and the Glycerol Monolaurate (GM) may eliminate oral H. pylori.

The $\mathrm{L}$ holds around $30 \mathrm{~L}$-lysine residues. They use ' $\mathrm{e}$ ' as a link with all Lysine molecules. Its surface has cationic. From electronically point view, the surface of $H$. pylori charges with positive power. The lysine amino acids are molecularly linked by the epsilon amino group and the carboxyl. If lysine meets with $H$. pylori in water, they will be having the very strong electronically huge power that making a cell of $H$. pylori attached with lysine molecules. The many liners of lysine molecules have clockwise and counter clockwise motion like a knife that tear membrane of $H$. pylori as fragments. The oral H. pylori will die.

We found GM exist in mother's milk that is nature preventive material for human's milk that formed by glycerol and lauric acid. In the water, GM will kill $H$. pylori immediately. We use Lysine and GM, called L-GM formed in mouth washing solution treat oral $H$. pylori infection. The patient uses it twice a day and $20 \mathrm{cc}$ each time with $5 \mathrm{~min}$ in the mouth. After 2 months, we found increasing efficacy of eradication on stomach infection about $21 \% .{ }^{1}$ These results of improvements had been confirmed by Saliva H. pylori culture (S-HP-C; Figure 2). On the basis of the confirmation of S-HP-C, we calculated the sensitivity, specificity, accuracy and positive and negative predictive values of HPS as 98.1, 94.1, 96.5, 96.2 and $97 \%$ respectively.

\section{CONCLUSION}

A colonized site of $H$. pylori can exist in the oral cavity. In medical practice, doctor consider patients had no stomach $H$. pylori infection. But in fact, patients can have negative results of UBT, but $H$. pylori exist in oral cavity. UBT cannot detect oral $H$. pylori.

If there is a live $H$. pylori colony in the oral cavity, then it would have a negative influence on the eradication of a stomach infection. In the classic $H$. pylori eradication programs, there are no clear measures of oral $H$. pylori; frequent relapses become more critical.

\section{CONFLICT OF INTEREST}

The author declares no conflict of interest.

\section{ACKNOWLEDGEMENTS}

I thank Dr Qilong Yi for statistical analyses and Bolina Long for figures analysis.

\section{PUBLISHER'S NOTE}

Springer Nature remains neutral with regard to jurisdictional claims in published maps and institutional affiliations.
1 Wang XM, Yee KC, Hazeki-Taylor N, Li J, Fu HY, Huang ML. Oral Helicobacter pylori, its relationship to successful eradication of gastric H. pylori and saliva culture confirmation. J Physiol Pharmacol 2014; 65: 559-566.

2 Anand PS, Kamath KP, Anil S. Role of dental plaque, saliva and periodontal disease in Helicobacter pylori infection. World J Gastroenterol 2014; 20: 5639-5653.

3 Sheu BS, Cheng HC, Yang YJ, Yang HP, Wu JJ. The presence of dental disease can be a risk factor for recurrent Helicobacter pylori infection after eradication therapy: a 3year follow-up. Endoscopy 2007; 39: 942-947.

4 Yee KC, Wei MH, Yee HC, Everett KD, Yee HP, Hazeki-Taylor N. A screening trial of Helicobacter pylori-specific antigen tests in saliva to identify an oral infection. Digestion 2013; 87: 163-169.

5 Huang R, Ding P, Huang D, Yang F. Antibiotic pollution threatens public health in China. Lancet 2015; 385: 773-774.

6 Dye BA, Kruszon-Moran D, McQuillan G. The relationship between periodontal disease attributes and Helicobacter pylori infection among adults in the United States. Am J Public Health 2002; 92: 1809-1815.

7 Fernández-Tilapa G, Axinecuilteco-Hilera J, Giono-Cerezo S, Giono-Cerezo S, Dinorah-Nashely MC, Illades-Aguiar B. vacA genotypes in oral cavity and Helicobacter pylori seropositivity among adults without dyspepsia. Med Oral Patol Oral Cir Bucal 2011; 16: e175-e180.

8 Nisha KJ, Nandakumar K, Shenoy KT, Janam P. Periodontal disease and Helicobacter pylori infection: a community-based study using serology and rapid urease test. J Investing Clin Dent 2016; 7: 37-45.

9 Tsami A, Petropoulou P, Kafritsa Y, Mentis YA, Roma-Giannikou E. The presence of Helicobacter pylori in dental plaque of children and their parents: is it related to their periodontal status and oral hygiene? Eur J Paediatr Dent 2011; 12: 225-230.

10 Lukeš P, Pavlík E, Potužníková B, Plzák J, Nártová E, Doseděl J et al. Comparison of Helicobacter pylori genotypes obtained from the oropharynx and stomach of the same individuals - a pilot study. Prague Med Rep 2012; 113: 231-239.

11 Ogaya Y, Nomura R, Watanabe Y, Nakano K. Detection of Helicobacter pylori DNA in inflamed dental pulp specimens from Japanese children and adolescents. J Med Microbiol 2015; 64(Pt 1): 117-123.

12 Ding YJ, Yan TL, Hu XL, Liu JH, Yu CH, Li YM. Association of salivary Helicobacter pylori infection with oral diseases: a cross-sectional study in a Chinese population. Int J Med Sci 2015; 12: 742-747.

13 Adler I, Muiño A, Aguas S, Harada L, Diaz M, Lence A. Helicobacter pylori and oral pathology: relationship with the gastric infection. World $\mathrm{J}$ Gastroenterol 2014; 20: 9922-9935.

14 Marbaix S, Soueidan1 A, Romani M, Campard G, Amador G, Badran Z. Helicobacter Pylori and periodontal diseases: an update and proposal of a multidisciplinary clinical protocol. Open J Stom 2013; 3: 318-322.

15 Ren Q, Yan X, Zhou Y, Li WX. Periodontal therapy as adjunctive treatment for gastric Helicobacter pylori infection. Cochrane Database Syst Rev 2016; 2: CD009477.

16 Sayed A, Anand PS, Kamath KP, Patil S, Preethanath RS, Anil S. Oral cavity as an extragastric reservoir of Helicobacter pylori. ISRN Gastroenterol 2014; 26: 1369.

17 Navabi N, Aramon M, Mirzazadeh A. Does the presence of the Helicobacter pylori in the dental plaque associate with its gastric infection? A metaanalysis and systematic review. Dent Res J (Isfahan) 2011; 8: 178-182.

18 Zheng $\mathrm{P}$, Zhou W. Relation between periodontitis and Helicobacter pylori infection. Int J. Clin Exp Med 2015; 8: 16741-16744.

19 Hardo PG, Tugnait A, Hassan F, Lynch DA, West AP, Mapstone NP et al. Helicobacter pylori infection and dental care. Gut 1995; 37: 44-46.

20 Veiga N, Pereira C, Resende C, Amaral O, Ferreira M, Nelas P et al. Oral and gastric Helicobacter pylori: effects and associations. PLOS ONE 2015; 10: e0126923.

21 Butt AK, Khan AA, Bedi R. Helicobacter pylori in dental plaque of Pakistanis. J Int Acad Periodontal 1999; 78: 78-82.

22 Dowsett SA, Kowolik MJ. Oral Helicobacter pylori, can we stomach it? Crit Rev Oral Biol Med 2003; 14: 226-233.

23 Namiot DB, Leszczyńska K, Namiot Z, Chilewicz M, Bucki R, Kemona A. The occurrence of Helicobacter pylori antigens in dental plaque; an association with oral health status and oral hygiene practices. Adv Med Sci 2010; 55: 167-171.

24 Silva DG, Stevens RH, Macedo JM, Albano RM, Falabella ME, Fischer RG et al. Presence of Helicobacter pylori in supragingival dental plaque of individuals with periodontal disease and upper gastric diseases. Arch Oral Biol 2010; 55: 896-901. 
25 Chaudhry S, Idrees M, Izhar M, Butt AK, Khan AA. Simultaneous amplification of two bacterial genes: more reliable method of Helicobacter pylori detection in microbial rich dental plaque samples. Curr Microbiol 2011; 62: 78-83.

26 Yang J, Zhang Q, Chen M. Association Between Helicobacter pylori Infection and Risk of Periodontal Diseases in Han Chinese: A CaseControl Study. Med Sci Monit 2016; 12: 121-126.

27 Gülseren D, Karaduman A, Kutsal D, Nohutcu RM. The relationship between recurrent aphthous stomatitis, and periodontal disease and Helicobacter Pylori infection. Clin Oral Investig 2016; 20 . 2055-2060.

28 Kazanowska-Dygdała M, Duś I, Radwan-Oczko M. The presence of Helicobacter pylori in oral cavities of patients with leukoplakia and oral lichen planus. J App/ Oral Sci 2016; 24: 18-23.

29 Lauritano D, Cura F, Candotto V, Gaudio RM, Mucchi D, Carinci F. Periodontal pockets as a reservoir of Helicobacter pylori causing relapse of gastric ulcer: A review of the literature. J Biol Regul Homeost Agents 2015; 29(3 Suppl 1): 123-126.

30 Chen J, He XL, Wu LL, Che T. The correlation between oral colonization of Helicobacter pylori and gastrointestinal disease. West China J Stom 2011 ; 29: 351-354.

31 Amiri N, Abiri R, Eyvazi M, Zolfaghari MR, Alvandi A. The frequency of Helicobacter pylori in dental plaque is possibly underestimated. Arch Oral Biol 2015; 60: 782-788.

32 Abadi AT, Mobarez AM, Teymournejad O, Karbalaei M. Concomitant colonization of Helicobacter pylori in dental plaque and gastric biopsy. J Pathog 2014; 87: 1601.

33 Yang K, Li Y, Zhou X. Overview of researches for Helicobacter pylori in oral cavity and stomach. Hua Xi Kou Qiang Yi Xue Za Zhi 2014; 32: 314-318.

34 Bharath TS, Reddy MS, Dhanapal R, Kumar NG, Neeladri RP, Saraswathi T. Molecular detection and correlation of Helicobacter pylori in dental plaque and gastric biopsies of dyspeptic patients. J Oral Maxillofac Pathol 2014; 18: 19-24.

35 Irani S, Monsef Esfahani A, Bidari Zerehpoush F. Detection of Helicobacter pylori in Oral Lesions. J Dent Res Dent Clin Dent Prospects 2013; 7: 230-237.

36 Boylan MR, Khalili H, Huang ES, Michaud DS, Izard J, Joshipura KJ et al. A prospective study of periodontal disease and risk of gastric and duodenal ulcer in male health professionals. Clin Trans/ Gastroenterol 2014; 13: e49.

37 Salazar CR, Francois F, Li Y, Corby P, Hays R, Leung C et al. Association between oral health and gastric precancerous lesions. Carcinogenesis 2012; 33: 399-403.

38 Cellini L, Grande R, Artese L, Marzio L. Detection of Helicobacter pylori in saliva and esophagus. New Microbiol 2010; 33: 351-357.

39 Bago I, Bago J, Plečko V, Aurer A, Majstorovic K, Budimir A. The effectiveness of systemic eradication therapy against oral Helicobacter pylori. J Oral Pathol Med 2011; 40: 428-432.

40 Mapstone NP, Lynch DAF, Lewis FA, Axon AT, Tompkins DS, Dixon MF et al. Identification of Helicobacter pylori DNA in the mouths and stomachs of patients with gastritis using PCR. J Clin Pathol 1993; 46: 540-543.

41 Oshowo A, Tunio M, Gillam D, Botha AJ, Holton J, Boulos P et al. Oral colonization is unlikely to play an important role in Helicobacter pylori infection. Br J Surg 1998; 85: 850-852.

42 Parsonnet J, Shmuely H, Haggerty BS. Fecal and oral shedding of Helicobacter pylori from healthy infected adults. J Am Med Assoc 1999; 282: 2240-2245.

43 Olsson K, Wadstrom T, Tyskiewicz T. H. pylori in dental plaques (letter). Lancet 1993; 341: 956-957.

44 Song Q, Lange T, Spahr A, Adler G, Bode G. Characteristic distribution pattern of Helicobacter pylori in dental plaque and saliva detected with nested PCR. J Med Microbiol 2000; 49: 349-353.

45 Momtaz H, Souod N, Dabiri H, Sarshar M. Study of Helicobacter pylori genotype status in saliva, dental plaques, stool and gastric biopsy samples. World J Gastroenterol 2012; 18: 2105-2111.

46 Young KA, Allaker RP, Hardie JM. Morphological analysis of Helicobacter pylori form gastric biopsies and dental plaque by scanning electron microscopy. Oral Microbiol Immunol 2001; 16: 178-181.

47 Rasmussen LT, Labio RW, Gatti LL, Silva LC, Queiroz VF, Smith Mde A et al. Helicobacter pylori detection in gastric biopsies, saliva and dental plaque of Brazilian dyspeptic patients. Mem Inst Oswaldo Cruz 2010; 105: 326-330.
48 Morales-Espinosa R, Fernandez-Presas A, Gonzalez-Valencia G, Flores-Hernandez S, Delgado-Sapien G, Mendez-Sanchez JL et al. Helicobacter pylori in the oral cavity is associated with gastroesophageal disease. Oral Micr Imm 2009; 24: 464-468.

49 Zaric S, Bojic B, Jankovic Lj, Dapcevic B, Popovic B, Cakic S et al. Periodontal therapy improves gastric Helicobacter pylori eradication. J Dent Res 2009; 88: 946-950.

50 Eskandari A, Mahmoudpour A, Abolfazli N, Lafzi A. Detection of Helicobacter pylori using PCR in dental plaque of patients with and without gastritis. Med Oral Patol Oral Cir Bucal 2010; 15: e28-e31.

51 Medina ML, Medina MG, Martín GT, Picón SO, Bancalari A, Merino LA. Molecular detection of Helicobacter pylori in oral samples from patients suffering digestive pathologies. Med Oral Patol Oral Cir Bucal 2010; 15: e38-e42.

52 Silva DG, Stevens RH, Macedo JM, Albano RM, Falabella ME, Veerman EC et al. Detection of cytotoxin genotypes of Helicobacter pylori in stomach, saliva and dental plaque. Arch Oral Biol 2009; 54: 684-688.

53 Al Asqah M, Al Hamoudi N, Anil S, Al Jebreen A, Al Hamoudi WK. Is the presence of Helicobacter pylori in dental plaque of patients with chronic periodontitis a risk factor for gastric infection? Can J Gastroenterol 2009 ; 23: 177-179.

54 Liu Y, Yue H, Li A, Wang J, Jiang B, Zhang Y et al. An epidemiologic study on the correlation between oral Helicobacter pylori and gastric $\mathrm{H}$. pylori. Curr Microbiol 2009; 58: 449-453.

55 Loster BW, Czesnikiewicz-Guzik M, Bielanski W, Karczewska E, Loster JE, Kalukin $\mathrm{J}$ et al. Prevalence and characterization of Helicobacter pylori (H. pylori) infection and colonization in dentists. J Physiol Pharmacol 2009; 60 (Suppl 8): 13-18.

56 Yee KC, Karin F, Hazeki-Taylor N. Further studies on the association of oral and stomach H. pylori infection. J China Dig 2011; 31: 38-41.

57 Yee KC. Second colonization site of Helicobacter pylori exist, in addition to primarily residing in the stomach. China Med Trib 2012; 23: D3.

58 Silva Rossi-Aguiar VP, Navarro-Rodriguez T, Mattar R, Siqueira de Melo Peres MP, Correa Barbuti R, Silva FM et al. Oral cavity is not a reservoir for Helicobacter pylori in infected patients with functional dyspepsia. Oral Microbiol Immunol 2009; 24: 255-259.

59 Dore-Davin C, Heitz M, Yang H, Herranz M, Blum AL, Corthésy-Theulaz I. Helicobacter pylori in the oral cavity reflects handling of contaminants but not gastric infection. Digestion 1999; 60: 196-202.

60 Miyabayashi H, Furhata K, Shimizu T, Ueno I, Akamatsu T. Influence of oral Helicobacter pylori on the success of eradication therapy against gastric Helicobacter pylori. Helicobacter 2000; 5: 30-37.

61 Gebara EC, Faria CM, Pannuti C, Chehter L, Mayer MP, Lima LA. Persistence of Helicobacter pylori in the oral cavity after systemic eradication therapy. J Clin Periodontol 2006; 33: 329-333.

62 Gao J, Li Y, Wang Q, Qi C, Zhu S. Correlation between distribution of Helicobacter pylori in oral cavity and chronic stomach conditions. J Huazhong Univ Sci Tech Med Sci 2011; 31: 409-412.

63 Song HY, Li Y. Can eradication rate of gastric Helicobacter pylori be improved by killing oral Helicobacter pylori? World J Gastroenterol 2013; 19: 6645-6650.

64 Zaric S, Bojic B, Jankovic Lj, Dapcevic B, Popovic B, Cakic S et al. Periodontal therapy improves gastric Helicobacter pylori eradication. J Dent Res 2009; 88: 946-950.

65 Sambashivaiah S, Bilichodmath S, Nanjaiah N. Helicobacter Pylori in periodontal pockets of chronic periodontitis patients with and without type II diabetes mellitus: a randomized controlled trial. Microbiol Res 2011; 2: e12.

66 Butt AK, Khan AA, Suleman BA, Bedi R. Randomized clinical trial of Helicobacter pylori from dental plaque. Br J Surg 2001; 88: 206.

67 Jia CL, Jiang GS, Li CH, Li CR. Effect of dental plaque control on infection of Helicobacter pylori in gastric mucosa. J Period 2009; 80: 1606-1609.

68 Cammarota G, laniro G, Bibbò S, Di Rienzo TA, Masucci L, Sanguinetti M et al. Culture-guided treatment approach for Helicobacter pylori infection: review of the literature. World J Gastroenterol 2014; 20: 5205-5211.

69 Yee JKC. Oral cavity is second colonized site beside stomach- a milestone discovery. World J Gastroenterol 2016; 22: 641-648.

70 Jonaitis L, Kiudelis G, Slepavicius P, Kupcinskas L. High rate of Helicobacter pylori reinfection in Lithuanian peptic ulcer patients. World J Gastrointest Pathophysiol 2016; 7: 181-185.

71 Zou QH, Li RQ. Helicobacter pylori in the oral cavity and gastric mucosa: a meta-analysis. J Oral Pathol Med 2011; 40: 317-324.

72 Di Rienzo TA, D'Angelo G, Ojetti V, Campanale MC, Tortora A, Cesario V et al. 13C-Urea breath test for the diagnosis of Helicobacter pylori infection. Eur Rev Med Pharmacol Sci 2013; 17(Suppl 2): 51-58. 
73 Ramírez-Lázaro MJ, Lario S, Calvet X, Sánchez-Delgado J, Montserrat A, Quílez EM et al. Occult $H$. pylori infection partially explains 'false-positive' results of (13)C-urea breath test. Uni Eur Gast J 2015; 3: 437-442.

74 Kushch I, Korenev N, Kamarchuk L, Pospelov A, Kravchenko A, Bajenov L et al. On the importance of developing a new generation of breath tests for Helicobacter pylori detection. J Breath Res 2015; 9: 04711.

75 Marshall B. A Meeting Speech at Helicobacter pylori infection of the Seventh National Forum of China. (Beijing, August 26-27, 2012).

76 Al-Ahmad A, Kürschner A, Weckesser S, Wittmer A, Rauberger H, Jakob T et al. Is Helicobacter pylori resident or transient in the human oral cavity? J Med Microbiol 2012; 61: 1146-1152.

77 Liu Q, Qi D, Kang J, Jin Y, Liu W, Gao W et al. Efficacy of real-time PCRbased detection of Helicobacter pylori infection and genotypic resistanceguided quadruple therapy as the first-line treatment for functional dyspepsia with Helicobacter pylori infection. Eur J Gastr Hepatol 2015; 27: 221-225.

78 Ismail H, Morgan C, Griffiths P. A newly developed nested PCR assay for the detection of Helicobacter pylori in the oral cavity. J Clin Gastr 2016; 50: 17-22.

79 Román-Román A, Giono-Cerezo S, Camorlinga-Ponce M, Martínez-Carrillo DN, Loaiza-Loeza S, Fernández-Tilapa G et al. vacA genotypes of Helicobacter pylori in the oral cavity and stomach of patients with chronic gastritis and gastric ulcer. Enferm Infecc Microbiol Clin 2013; 31: 130-135.

80 Krajden S, Fuksa M, Anderson J, Kempston J, Boccia A, Petrea C et al. Examination of human stomach biopsies, saliva, and dental plaque for Campylobacter pylori. J Clin Micr 1989; 27: 1397-1398.

81 Cheng LH, Webberley M, Evans M, Hanson N, Brown R. Helicobacter pylori in dental plaque and gastric mucosa. Oral Surg Oral Med Oral Pathol Oral Radiol Endod 1996; 81: 421-423.

82 Luman W, Alkout AM, Blackwell CC, Weir DM, Plamer KR. Helicobacter pylori in the mouth - negative isolation from dental plaque and saliva. Eur J Gastr Hepatol 1996; 8: 11-14.

83 Allaker RP, Young KA, Hardie JM, Domizio P, Meadows NJ. Prevalence of Helicobacter pylori at oral and gastrointestinal sites in children: evidence for possible oral-to-oral transmission. J Med Micr 2002; 51: 312-317.

84 Bernander S, Dalen J, Gastrin B, Hedenborg L, Lamke LO, Ohrn R. Absence of Helicobacter pylori in dental plaques in Helicobacter pylori positive dyspeptic patients. Eur J Clin Microbiol Infect Dis 1993; 12: 282-285.

85 Pustorino R, Nicosia R, D’Ambra G, Di Paola M, Brugnoletti O, Grippaudo G et al. The mouth-stomach crossing of Helicobacter pylori. Eur Rev Med Pharmacol Sci 1996; 18: 183-186.

86 Khandaker K, Palmer KR, Eastwood MA, Scott AC, Desai M, Owen RJ. DNA fingerprints of Helicobacter pylori from mouth and antrum of patients with chronic ulcer dyspepsia (letter). Lancet 1993; 342: 751.

87 Ishihara K, Miura T, Kimizuka R, Ebihara Y, Mizuno Y, Okuda K. Oral bacteria inhibit Helicobacter pylori growth. FEMS Micr Lett 1997; 152: 355-361.

88 Majmudar P, Shah SM, Dhunjbhoy KR, Desai HG. Isolation of Helicobacter pylori from dental plaques in healthy volunteers. Ind J Gast 1990; 9: 271-272.

89 Cellini L, Allocati N, Piattelli A, Petrelli I, Fanci P, Dainelli B. Microbiological evidence of Helicobacter pylori from dental plaque in dyspeptic patients. Micr 1995; 18: 187-192.

90 Wahlfors J, Meurman JH, Toskala J. Development of a rapid PCR method for identification of Helicobacter pylori in dental plaque and gastric biopsy specimens. Eur J Clin Microbiol Infect Dis 1995; 14: 780-786.

91 Namavar F, Roosendaal R, Kuipers EJ. Presence of Helicobacter pylori in the oral cavity, oesophagus, stomach and faeces of patients with gastritis. Eur J Clin Microbiol Infect Dis 2001; 14: 234.

92 D'Alessandro A, Seri S. Comparison of three different methods for evaluation of Helicobacter pylori in human dental plaque. Boll Soc it Biol Sper 1992; 68: 769-773.

93 Ferguson DA, Li C, Patel NR, Mayberry WR, Chi DS, Thomas E. Isolation of Helicobacter pylori from saliva. J Clin Microbiol 1993; 31: 2802-2804.

94 Bickley J, Owen RJ, Fraser AG. pounder RE. Evaluation of the polymerase chain reaction for detecting the urease $\mathrm{C}$ gene of Helicobacter pylori in gastric biopsy samples and dental plaque. J Med Microbiol 1993; 39: 338-344.

95 Zheng QM, Zhu T, Shen BD. Helicobacter pylori in dental plaque and its relevance to chronic gastritis. J China Microb 2006; 18: 369-370.
96 Zheng Y, Cheng ZJ, He SC. Helicobacter pylori in patients with gastrointestinal diseases use saliva testing. Modern Stomato 2012; 26: 383-386.

97 Jiang Y, Chen TY, Wei YC. Three methods detecting $H$. pylori of oral cavity. ACTA Nanchang University China 2011; 51: 60-62.

$98 \mathrm{Xu} \mathrm{LH}, \mathrm{Gu} \mathrm{HY}$, Wu Z. The effectiveness of mouth washing solution on $\mathrm{H}$. pylori of oral cavity. Oral Med China 2001; 21: 142-143.

99 Agarwal S, Jithendra KD. Presence of Helicobacter pylori in subgingival plaque of periodontitis patients with and without dyspepsia, detected by polymerase chain reaction and culture. J Indian Soc Periodontol 2012; 16: 398-403.

100 Czesnikiewicz-Guzik M, Bielanski W, Guzik TJ, Loster B, Konturek SJ. Helicobacter pylori in the oral cavity and its implications for gastric infection, periodontal health, immunology and dyspepsia. J Physiol Pharmacol 2005; 56(Suppl 6): 77-89.

101 Cześnikiewicz-Guzik M, Karczewska E, Bielański W, Guzik TJ, Kapera P, Targosz A et al. Association of the presence of Helicobacter pylori in the oral cavity and in the stomach. J Physiol Pharmacol 2004; 55(Suppl 2): $105-115$.

102 Wagner S, Beil W, Mai UE, Bokemeyer C, Meyer HJ, Manns MP. Interaction between Helicobacter py/ori and human gastric epithelial cells in culture: effect of antiulcer drugs. Pharmacology 1994; 49: 226-237.

103 Sudhakar U, Anusuya CN, Ramakrishnan T, Vijayalakshmi R. Isolation of Helicobacter pylori from dental plaque: A microbiological study. J Indian Soc Periodontol 2008; 12: 67-72.

104 Teoman I, Ozmeriç N, Ozcan G, Alaaddinoğlu E, Dumlu S, Akyön Y et al. Comparison of different methods to detect Helicobacter pylori in the dental plaque of dyspeptic patients. Clin Oral Investig 2007; 11: 201-205.

105 Umeda M, Kobayashi H, Takeuchi Y, Hayashi J, Morotome-Hayashi Y, Yano $\mathrm{K}$ et al. High prevalence of Helicobacter pylori detected by PCR in the oral cavities of periodontitis patients. J Periodontol 2003; 74: 129-134.

106 Goosen C, Theron J, Ntsala M, Maree FF, Olckers A, Botha SJ et al. Evaluation of a novel heminested PCR assay based on the phosphoglucosamine mutase gene for detection of Helicobacter pylori in saliva and dental plaque. J Clin Microbiol 2002; 40: 205-209.

107 Checchi L, Felice P, Acciardi C, Ricci C, Gatta L, Polacci R et al. Absence of Helicobacter pylori in dental plaque assessed by stool test. $\mathrm{Am} \mathrm{J}$ Gastroenterol 2000; 95: 3005-3006.

108 Song Q, Zirnstein GW, Swaminathan B, Gold BD. Pretreatment with UreaHydrochloric Acid Enhances the Isolation of Helicobacter pylori from Contaminated Specimens. J Clin Microbiol 2001; 39: 1967-1968.

109 Song Q, HallerB, Ulrich A, Wichelhaus A, Adler G, Bode G. Quantitation of Helicobacter pylori in dental plaque samples by competitive polymerase chain reaction. J Clin Pathol 2000; 53: 218-222.

110 Furuta T, Kaneko E, Suzuki M, Arai H, Futami H. Quantitative study of Helicobacter pylori in gastric mucus by competitive PCR Using synthetic DNA fragments. J Clinic Microbiol 1996; 34: 2421-2425.

111 Dowsett SA, ArchilaL, SegretoVA, Gonzalez CR, Silva A, Vastola KA et al. Helicobacter pylori infection in indigenous families of Central America: serostatus and oral and fingernail carriage. J Clin Microbiol 1999; 37: 2456-2460.

112 Dewhirst FE, Chen T, Izard J, Paster BJ, Tanner AC, Yu WH et al. The human oral microbiome. J Bacteriol 2010; 192: 5002-5017.

113 Singh V, Trikha B, Vaiphel K, Nain CK, Thennarasu K, Singh K. Helicobacter pylori: evidence for spouse-to-spouse transmission. J Gastroenterol Hepatol 1999; 14: 519-522.

114 Schutze K, Hentschel E, Dragosics B, Hirschi AM. Helicobacter pylori reinfection with identical organisms:transmission by the parents' spouses. Gut 1995; 36: 831-833.

115 Zenilman JM. Ethnicity and sexually transmitted infections. Curr Opin Infect Dis 1998; 11: 47-52.

116 Mollison LC, Lecons RJ, Thein-Htut, Rajabalendaran N, Perera C. Upper gsatrointestinal endoscopy in central Australian aborigines. Med J Aust 1994; 160: 182-184.

117 Eslick GD. Hp infection transmitted sexual via oralgenital contact: a hypothetical mode. Sex Tran 2000; 76: 489-492.

118 Minakami $\mathrm{H}$, Hayashi $\mathrm{M}$, Sato I. Does $\mathrm{Hp}$ colonize the vagina of pregnant women? J Infect 2000; 41: 112-113.

119 Blecker U, Lanciers S, Keppens E, Vandenplas Y. Evolution of Helicobacter pylori positivity in infants born from positive mothers. J Pediatr Gastroenterol Nutr 1994; 19: 87-90. 
120 Yan P, Eslick GD. Xia HH-X. Association between Helicobacter pylori infection and fetal intrauterine growth retardation (IUGR). Gastroenterology 2000; 118(suppl 2): A734.

121 Kast RE. Some fibrocystic breast change may be caused by sexually transmitted $H$. pylori during oral nipple contact: Supporting literature and case report of resolution after gut $H$. pylori eradication treatment. Med Hypotheses 2007; 68: 1041-1046.

122 Fujimura S, Kato S, Nagai K, Kawamura T, linuma K. Detection of Hp in the stools of newborn infants. Pediatr Infect Dis J 2004; 23: 1055-1056.

123 Kitagawa M, Natori M, Katoh M, Sugimoto K, Omi H, Akiyama Y et al. Maternal transmission of $\mathrm{Hp}$ in the period. J Obstet Gynaecol Res 2001; 27: 225-230.

124 Eslick GD. Non-gonococcal urethritis, Helicobacter pylori infection and fellatio: a new me' nage a'trois? Microbiology 2004; 150: 520-522.

125 Siavoshi F, Taghikhani A, Malekzadeh R, Sarrafnejad A, Kashanian M, Jamal AS et al. The role of mother's oral and vaginal yeasts in transmission of Helicobacter pylori to neonates. Arch Iran Med 2013; 16: 288-294.

126 Dimitriadi D. Helicobacter pylori: a sexually transmitted bacterium? Cent Eur J Urol 2014; 67: 407-409.

127 Chow TK, Lambert JR, Wahlqvist ML, Hsu-Hage BH. Helicobacter pylori in Melbourne Chinese immigrants: evidence for oral-oral transmission via chopsticks. J Gastroenterol Hepatol 1995; 10: 562-569.

128 Malaty HM, El-Kasabany A, Graham D, Miller CC, Reddy SG, Srinivasan SR et al. Age at acquisition of Helicobacter pylori infection: a follow-up study from infancy to adulthood. Lancet 2002; 359: 931-935.
129 Malaty HM. Epidemiology of Helicobacter pylori infection. Best Pract Res Clin Gastroenterol 2007; 21: 205-214.

130 Weyermann M, Rothenbacher D, Brenner H. Acquisition of Helicobacter Pylori infection in early childhood: independent contributions of infected mothers, fathers, and siblings. Am J Gastroenterology 2009; 104: 182-189.

131 Goh KL, Chan WK, Shiota S, Yamaoka Y. Epidemiology of Helicobacter pylori Infection and Public Health Implications. Helicobacter 2011; 16(Suppl 1): 1-9.

(c) (1) This work is licensed under a Creative Commons Attribution 4.0 International License. The images or other third party material in this article are included in the article's Creative Commons license, unless indicated otherwise in the credit line; if the material is not included under the Creative Commons license, users will need to obtain permission from the license holder to reproduce the material. To view a copy of this license, visit http:// creativecommons.org/licenses/by/4.0/

(C) The Author(s) 2017 